\title{
Histone Deacetylase 11
}

National Cancer Institute

\section{Source}

National Cancer Institute. Histone Deacetylase 11. NCI Thesaurus. Code C104289.

Histone deacetylase 11 (347 aa, $39 \mathrm{kDa}$ ) is encoded by the human HDAC11 gene. This protein is involved in both histone deacetylation and transcriptional regulation. 